\title{
Temporal dynamics of arsenic uptake and distribution: food and water risks in the Bengal basin
}

Sarath Pullyottum Kavil, Devanita Ghosh, Indira Pasic and Joyanto Routh

The self-archived postprint version of this journal article is available at Linköping University Institutional Repository (DiVA):

http://urn.kb.se/resolve?urn=urn:nbn:se:liu:diva-167710

N.B.: When citing this work, cite the original publication.

This is an electronic version of an article published in:

Kavil, S. P., Ghosh, D., Pasic, I., Routh, J., (2020), Temporal dynamics of arsenic uptake and distribution: food and water risks in the Bengal basin, Toxicological \& Environmental Chemistry, 102(1-4), 62-77. https://doi.org/10.1080/02772248.2020.1767781

Original publication available at:

https://doi.org/10.1080/02772248.2020.1767781

Copyright: Taylor and Francis

http://www.tandf.co.uk/journals/default.asp 


\title{
1 Temporal dynamics of Arsenic uptake and distribution: Food and
}

\section{2 water risks in the Bengal basin}

\author{
Sarath P.K. ${ }^{\text {, }}$, Devanita Ghosh ${ }^{\mathrm{a}, 1}$, Indira Pašićc ${ }^{\mathrm{b}}$, Joyanto Routh ${ }^{\mathrm{b}}$ \\ aLaboratory of Biogeochem-mystery, Centre for Earth Sciences, Indian Institute of Science, \\ Bangalore, India \\ ${ }^{b}$ Department of Thematic Studies-Environmental Change, Linköping University, Linköping, \\ Sweden
}

\section{Abstract}

Contaminated food chain is a serious contender for arsenic (As) uptake around the globe. In Nadia, West Bengal, we trace possible means of transfer of As from multiple sources reaching different trophic levels, and associated seasonal variability leading to chronic As uptake. This work considers possible sources-pathways of As transfer through food chain in rural community. Arsenic concentration in groundwater, soil, rice, and vegetable-samples collected detected in different harvest seasons of 2014 and 2016. Arsenic level in shallow groundwater samples ranged from 0.1 to $354 \mu \mathrm{g} / \mathrm{L}$, with $75 \%$ of the sites above the prescribed limit by WHO $(10 \mu \mathrm{g} / \mathrm{L})$ during the boro harvest season. High soil As content $(\sim 20.6 \mathrm{mg} / \mathrm{kg})$, resulted in accumulation of As in food crops. A positive correlation in As conc. with increase over period in all sites indicating gradual As accumulation in topsoil. Unpolished rice samples showed high As content $(\sim 1.75 \mathrm{mg} / \mathrm{kg})$, polishing reduced $80 \%$ of As. Among vegetables, the plant family Poaceae with high irrigation requirements and Solanaceae retaining high moisture, have the highest levels of As. Contaminated animal fodder (Poaceae) and turf water for cattle are shown to contaminate milk (0.06 to $0.24 \mu \mathrm{g} / \mathrm{L})$ and behoves strategies, practices to minimize As exposure.

Keywords: Arsenic; Vegetables; Paddy; Food intoxication; Health risk

\footnotetext{
${ }^{1}$ Corresponding author: devanita@iisc.ac.in, Tel: +91-80 22932633;

Laboratory of Biogeochem-mystery, Centre for Earth Sciences, Indian Institute of Science, Bangalore, India
} 


\section{Introduction}

Arsenic contaminated groundwater has posed a major global threat to human health for the past three decades. The sub-surface shallow and deep aquifers in the Bengal basin are a perennial source of fresh, potable groundwater that is widely used to bypass the use of contaminated surface water that might have enteric bacteria due to open defecation practice. In the last few decades, intensive research in this field has firmly established the geogenic pathways, and biogeochemical processes playing a key role in As cycling and contaminating the aquifers leading to severe health hazards (Nickson et al. 1998; Bhattacharya et al. 2007; Chikkanna et al. 2019).

The other routes of As intoxication in humans are through the consumption of contaminated cereals, vegetables, dairy products, and livestock that are usually ignored (Datta et al. 2010). Other than health-related issues, contamination of As in cereals has, in particular, affected the export of Basmati rice from South East Asian countries (FAO 2011). The highly fertile fluvial plain of rivers in SE Asian countries such as the Ganges, Meghna, and Brahmaputra river plains in India and Bangladesh, the Mekong river delta in Cambodia, Red river delta in Vietnam, Pearl River delta in China, Choushui River alluvial fan in Taiwan are some of the worst affected regions in the world. Amongst these cases, the Gangetic river delta has alone affected more than $2 \%$ of the global population (Mukherjee 2018).

The Gangetic plain, being fertile, is widely used for paddy cultivation for local consumption and export. Paddy is cultivated twice per annum and known as Aman (from the Arabic word for tranquillity) and Boro (protection against torture) cultivation. Aman is sown during the monsoon (July-August) and harvested in winter (late November to early December). The Boro crop was introduced after the green revolution started in the 1960s. The crop is sown during winters (January-February) and harvested in summer (April-May). While the Aman cultivation is rain-fed, the Boro cultivation was developed depending on the groundwater supply for irrigation system (Roberts et al. 2010; Ghosh, Routh, and Bhadury 2017). Since paddy cultivation demands a lot of water, the source of water used for irrigation plays an important role in the level of accumulation and contamination of heavy metals by the crop. In the rhizospheric anaerobic microenvironments, many elements get reduced [e.g. $\operatorname{As}(\mathrm{V})$ to $\mathrm{As}(\mathrm{III})$ and $\mathrm{Fe}(\mathrm{III})$ into $\mathrm{Fe}(\mathrm{II})$ ], which promote their uptake through the aquaporins, nodule 26-like intrinsic proteins (NIPs), phosphate transporter and accumulate in the tissues (Ma et al. 2008). 
Agriculture is the major occupation in rural India and the country has made spectacular advances in multiple cropping and growing high-yield cereals, particularly rice, which is a major output. It is observed that groundwater irrigation practices in the Bengal Basin for more than three decades, has enriched the topsoil with the contaminants derived from groundwater (Meharg and Rahman 2003; Norra et al. 2005). Enhanced crop production in the region to meet the regional demand mandates intense crop irrigation which is met by extensive use of groundwater. This leads to the accumulation of As in soil which is taken up by food crops (Banerjee et al. 2013). This aspect in turn adversely affects the health of the crop and its yield due to As related phytotoxicity as reported in many recent studies (Roberts et al., 2010).Hence, the objective of this study is to understand the uptake of As in cereals and vegetables in one of the worst affected regions (namely the Nadia district in West Bengal) as an example to infer the transport, transformation, and accumulation of As in agricultural products widely consumed locally or exported to other markets. The main objectives of the present study are to understand (i) the temporal changes in As fluxes in the natural reservoirs, (ii) understanding the dynamics of As in crops along the course of Ganges River in Nadia district, and iii) identifying the routes of human As-toxicosis other than drinking water. This knowledge will be useful in policy making and mitigation efforts to launch agricultural practices which will be helpful in reducing As and other toxic metals by plants forming part of staple diets in large populations.

\section{Study area}

The lower Gangetic plain in India mostly covers the state West Bengal, where most of the districts are known as "As-hot spots" for their highly contaminated aquifers (Bhattacharya et al. 2007; Nath et al. 2005). Among these, Nadia is the worst affected district (Ghosh et al. 2015; Ghosh, Bhadury, and Routh 2014; Ghosh, Routh, and Bhadury 2017), where $>15 \%$ of the population is affected by arsenicosis (Mazumder et al. 2010). A total of twelve sampling sites (Fig. 1) were selected across the district from blocks (administrative sub-divisions) that have high As levels in groundwater and soils namely: Haringhata (stations S1, S2, and S3), Chakdah (stations S4 to S8), Ranaghat I (station S9), Tehatta I (station S10), and Karimpur II (station S11 and S12). The average annual rainfall in the district is $113 \mathrm{~mm}$ and the maximum is $287 \mathrm{~mm}$ during the month of July (Climate data-WB-Nadia).

\section{Material and Method}




\subsection{Sampling}

104 Paddy, seasonal vegetables, cattle fodder crop, water fed to cattle (turf water), and raw cow milk (from villagers) along with groundwater from agricultural fields were collected in twelve stations (sample details listed in Table S1), during the Aman and Boro harvest periods of 2014 and 2016. The surface soil samples were collected only during the boro harvest season in 2014 and 2016. The vegetable samples were collected in sterile zip-lock bags sent to the Indian Institute of Science Education and Research, Kolkata, where they were rinsed with $2 \% \mathrm{HNO}_{3}$ (Merck, Darmstadt, Germany), weighed and cut (if needed) prior to drying at

$11150{ }^{\circ} \mathrm{C}$ in a hot air oven. All the samples were packed in sterile zip-lock bags and weighed

112 before shipping them to Linköping University, Sweden for further analyses. The groundwater

113 samples and the milk samples were acidified with 2-3 drops of concentrated $\mathrm{HNO}_{3}$ (Merck,

114 Darmstadt, Germany) and the water samples were filtered through a $0.45 \mu \mathrm{m}$ filter during 115 sampling.

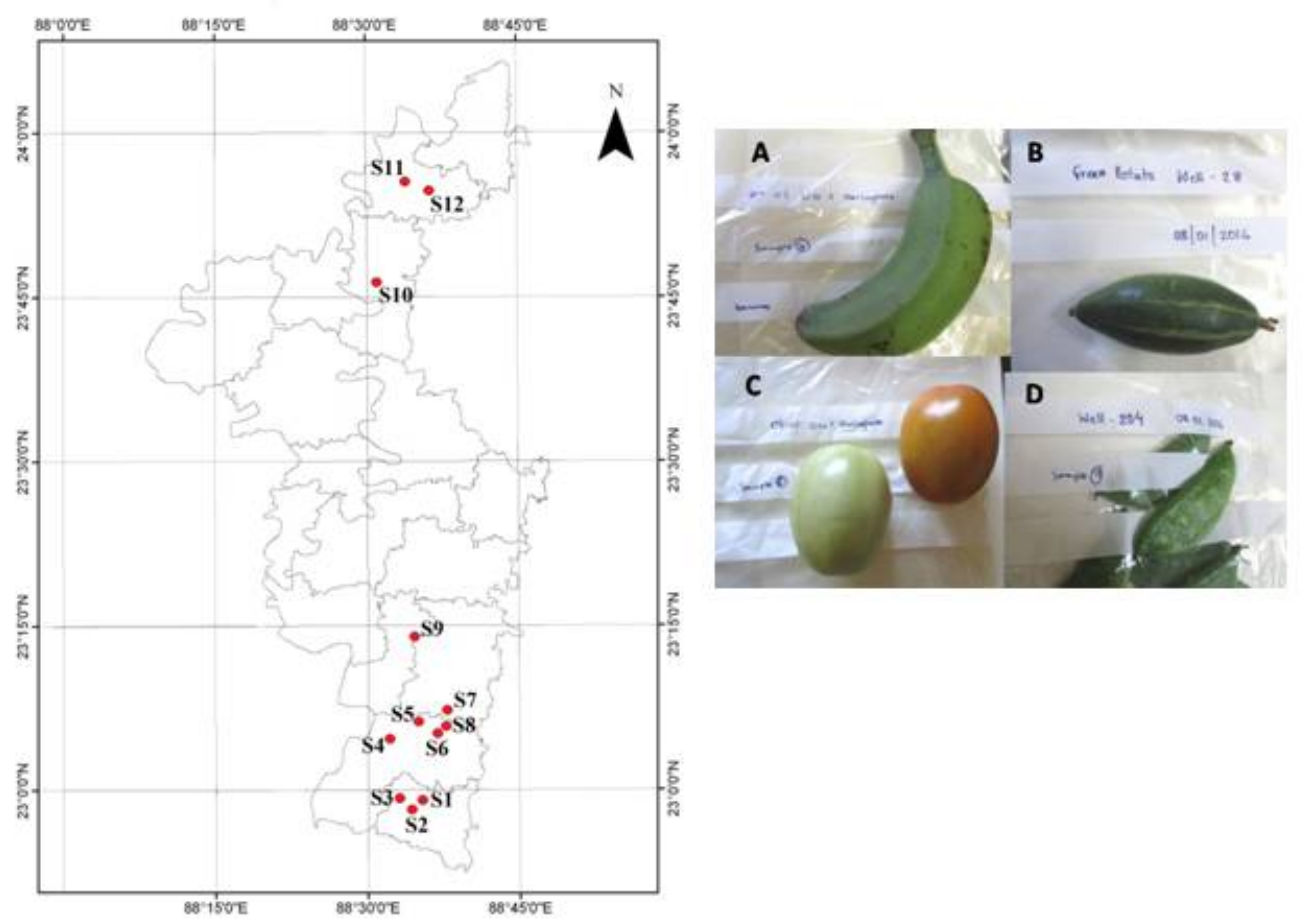

117 Fig. 1. On left: Map of Nadia district (WB, India), showing the location of sampling sites (S1 118 to S12). On right: Vegetable samples collected from the field A. Banana (Musca sp.,) B.

119 Pointed gourd (Trichosanthes_dioica), C. Tomato (Solanum lycopersicum), D. Flat bean 120 (Phaseolus vulgaris). 
123 All the dried samples were crushed, homogenized and $0.5 \mathrm{~g}$ of dried vegetables and sediment

124 samples were accurately weighed (Mettlesr AE200-S, Mettler Toledo; Ohio, USA) and added

125 to acid-washed Teflon tubes, followed by $2 \mathrm{ml}$ of $30 \% \mathrm{H}_{2} \mathrm{O}_{2}$ (Merck) and $8 \mathrm{ml}$ of suprapure

$126 \mathrm{HNO}_{3}$ (Merck). The vessels were tightly sealed and digested in a microwave digester (Ethos

127 UP; Milestone Srl, Sorisole, Italy) for a ramping period of $30 \mathrm{mins}$ followed by a hold period

128 for $15 \mathrm{mins}$ at $200{ }^{\circ} \mathrm{C}$ and $1500 \mathrm{~W}$ power. The digest was extracted and filtered $(0.45 \mu \mathrm{m})$

129 before quantifying the elemental concentration on an inductively coupled plasma-mass

130 spectrometer (Perkin ElmerNexION 300D). The detection limits for the different trace metals

131 are detailed in Table S1.

132

133 3.3. Quality assurance

134 Reference materials i) SMR 1547 (Peach leaf) certified by National Institute of Standards and

135 Technology (NIST; Maryland, USA) supplied by Sigma-Aldrich (Missouri, USA), ii) BCR

136 Reference Material Nr. 62 Olea europea (Olive leaves) certified by Community Bureau of

137 Reference, European Commission supplied by Merck (Darmstadt, Germany), and iii) Peat

138 standard NIMT/UOE/FM/001 (Yafa et. al., 2004) supplied by Sigma-Aldrich (Missouri,

139 USA), were also acid digested in the microwave digest using the same procedure and

140 analysed (Table S2).

141

142

143 The concentration of As was measured in samples from shallow groundwater wells at the

144 sampling stations (17-40 $\mathrm{m}$ depth) which are routinely used for irrigation of the adjacent

145 agricultural fields (Fig.2).The As concentration in groundwater ranged from 0.14 to $354 \mu \mathrm{g} / 1$

146 with the highest value recorded at Sahishpur (S5), during the boro season in 2016. Arsenic

147 content in several groundwater wells crossed the recommended threshold limit for irrigation

148 water $(100 \mu \mathrm{g} / \mathrm{L}, \mathrm{EU})$. The As concentrations in groundwater samples were higher during the

149 boro season when compared to the aman season at all the stations. 


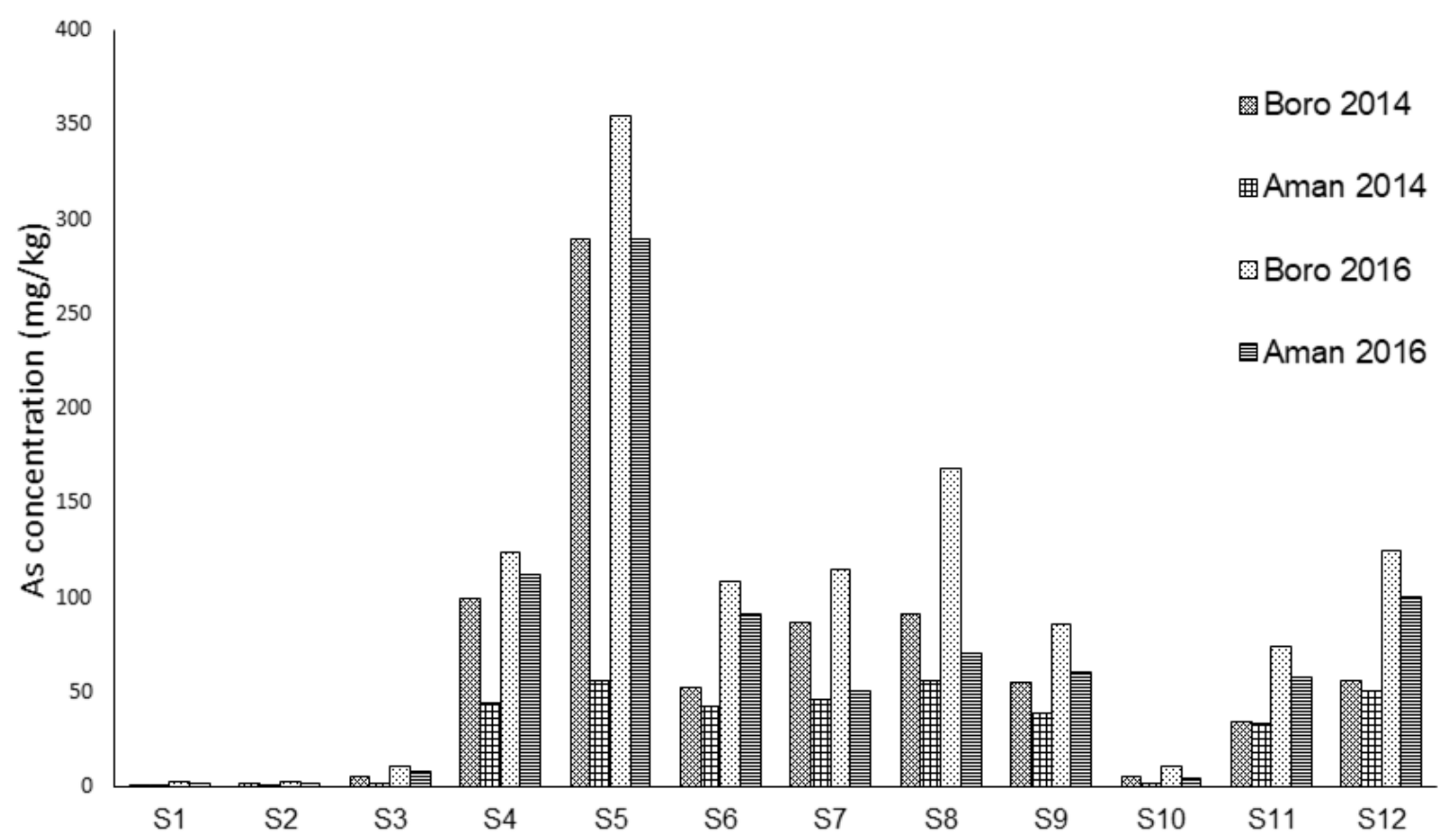

151 Figure 2. Arsenic concentration in groundwater samples collected from 12 sites in Nadia 152 district across two seasons in 2014 and 2016.

154 In the paddy soils, As concentration ranged from 2.5 to $20.6 \mathrm{mg} / \mathrm{kg}$ (Fig.3a). The As content 155 in soil from nine out of the twelve sites exceeded the average world content in the natural 156 soils of $5 \mathrm{mg} / \mathrm{kg}$ (Kabata-Pendias 2001), indicating accumulation of As due to the use of 157 contaminated water for irrigation over a long period. The typical concentration of As in soil 158 varies between 0.1 to $10 \mathrm{mg} / \mathrm{kg}$ (Kabata-Pendias 2001). The mean As concentration in soil 159 from our study (11.8 mg/kg; ranging from 2.5 to $28.6 \mathrm{mg} / \mathrm{kg}$ ) was similar to the values 160 reported for agricultural tracts in West Bengal (Roychowdhury et al. 2002), but lower than 161 the recent study from Chakdaha block (47-62.5 mg/kg; Upadhyay et al. 2019). In Fig.3b, As 162 concentration in soil showed a significant positive correlation with the As concentration in 163 irrigation water $(\mathrm{r}=0.61317, \mathrm{p}<<0.01)$. In particular, stations S4, S8, and S12 indicated As 164 concentration above the maximum acceptable level in agricultural soils of $20 \mathrm{mg} / \mathrm{kg}$ during 1652016 sampling. 
166
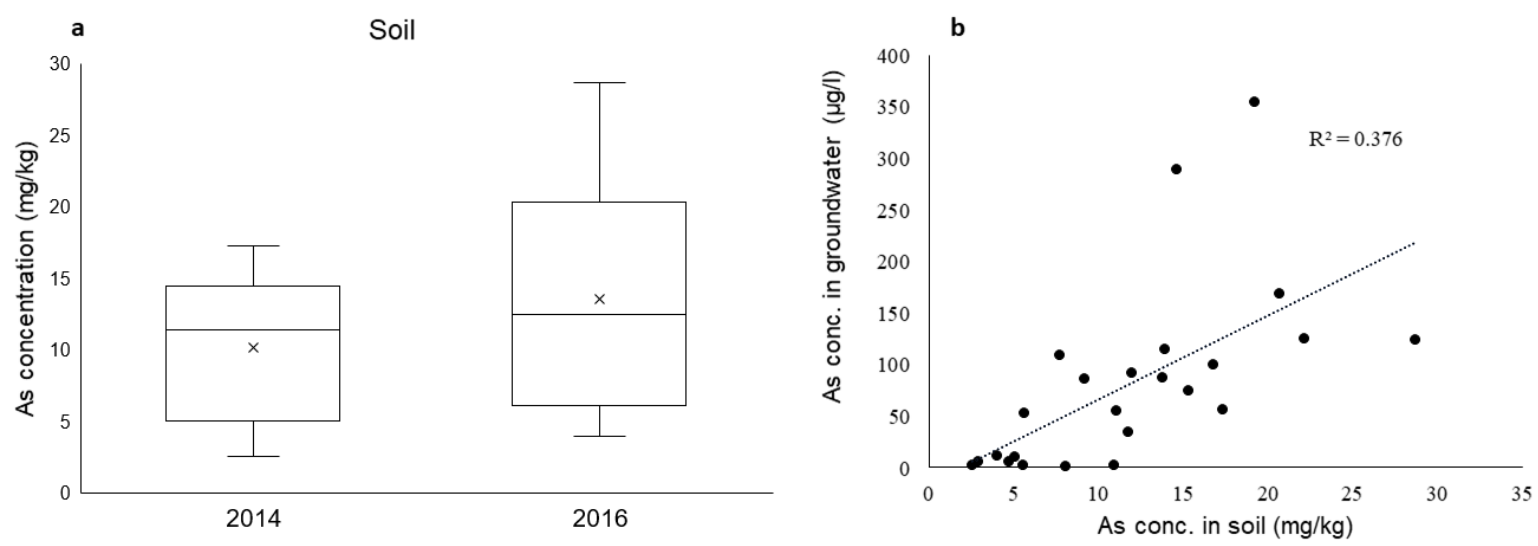

Figure 3. a) Arsenic concentration in agricultural soils collected near the irrigation well at the end of the year (aman season), b) correlation plot between arsenic in groundwater and arsenic in soil for the boro season in 2014 and 2016.

Total As content in rice grains from multiple plants collected from 12 sites during the boro and aman harvest-seasons in 2014 and 2016. Arsenic varied from 83.4 to $4879 \mu \mathrm{g} / \mathrm{kg}$ of with a mean value of 4181 and $1255 \mu \mathrm{g} / \mathrm{kg}$ during the boro and aman harvest seasons, respectively. The polished rice grains from the field which are sold in local village markets were studied to understand the effect of polishing the rice kernels on As levels. The average value of As in unpolished and polished rice during the dry and wet season was 2.58, 0.93, 0.46 and 0.19 $\mu \mathrm{g} / \mathrm{kg}$, respectively. Many unpolished rice grains from the boro season in 2014 and all rice grain in 2016 exceeded the recommended threshold limit of $1000 \mu \mathrm{g} / \mathrm{kg}$. The highest concentration was reported at Site 7 during the boro season in 2016 with a concentration of $4.9 \mathrm{mg} / \mathrm{kg}$ As in raw rice grain.
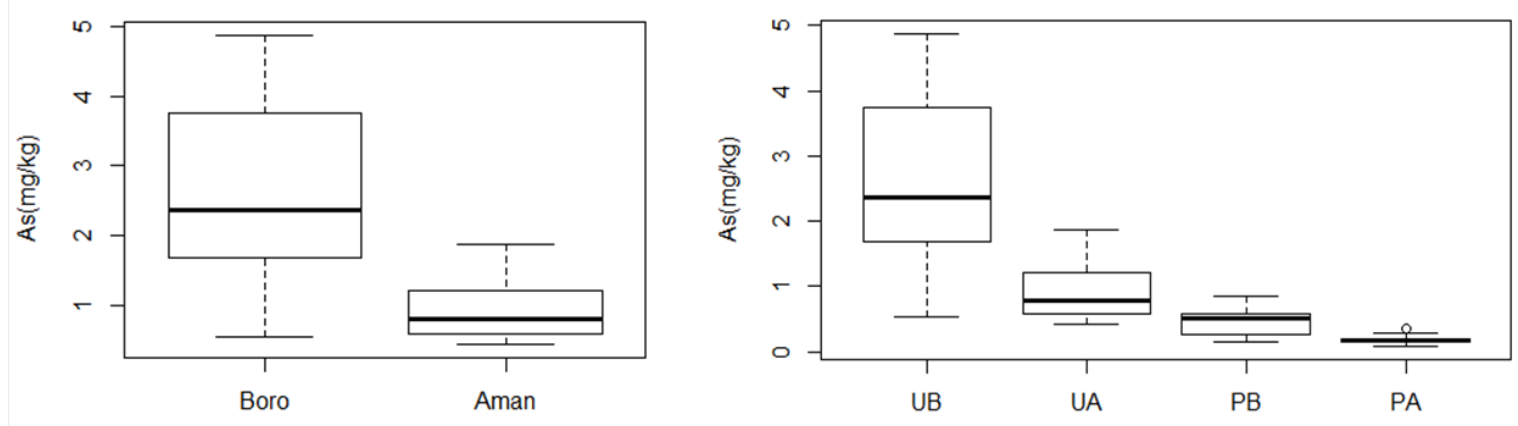

181

182 Figure 4. a) Box plot showing change in As concentration in rice grain during the boro and aman seasons, b) As concentration in polished and unpolished rice during different season

184 (UB-unpolished boro, UA-unpolished aman, PB-polished boro, PA-polished aman). 
We further assessed As concentration in seasonal vegetables commonly grown in the study region. Mean and range of As concentration in seven vegetables are shown in Table 1 and Fig S2.The vegetables were grown in close proximity to the rice field and were irrigated with groundwater from the same shallow wells. Available vegetables were collected from different sites and they were analysed separately. The highest As concentration was noted in pointed gourds collected from both 2014 and $2016(1.03 \mathrm{mg} / \mathrm{kg}, \mathrm{n}=12)$. The order of mean As concentration $(\mathrm{mg} / \mathrm{kg}$ dry weight) in vegetables are as follows: bottle gourd and pointed gourd (0.39) >chilli (0.16) > eggplant $(0.12)>$ tomato $(0.05)>$ banana $(0.02)>$ flat bean $(0.01)$.

Table 1. The mean As concentration and range in vegetables from the study region (vegetable samples were collected during both seasons in 2014 and 2016)

\begin{tabular}{|c|c|c|}
\hline Vegetable & $\begin{array}{c}\text { Mean As conc. } \\
(\mathrm{mg} / \mathrm{kg})\end{array}$ & Range (mg/kg) \\
\hline Bottle gourd (Lagenaria siceraria) & $0.39(n=12)$ & $0.2-0.73$ \\
\hline Flat bean (Phaseolus vulgaris) & $0.01(n=9)$ & $0.001-0.18$ \\
\hline Tomato (Solanum lycopersicum) & $0.05(n=4)$ & $0.01-0.078$ \\
\hline Banana (Musca sp.) & $0.02(n=5)$ & $0-0.06$ \\
\hline Egg plant (Solanum melongena) & $0.12(n=12)$ & $0.04-.0256$ \\
\hline Pointed gourd (Trichosanthes dioica) & $0.39(n=12)$ & $0.121-1.025$ \\
\hline Chilli (Capsicum frutescens) & $0.16(n=7)$ & $0.01-0.49$ \\
\hline
\end{tabular}

Three vegetables cultivated during both the boro and aman harvest seasons were selected for the temporal study. Temporal changes in As concentration of vegetables during the boro and aman harvest are shown in Fig 5. Temporal trend in As concentration of vegetables were similar to the irrigated groundwater during the boro harvest (Fig 5). The highest As concentration was observed in boro during 2016 for all three types of vegetables. The highest concentration occurred in pointed gourd $(1.03 \mathrm{mg} / \mathrm{kg})$ exceeding the food hygiene limit of 1 $\mathrm{mg} / \mathrm{kg}$. 


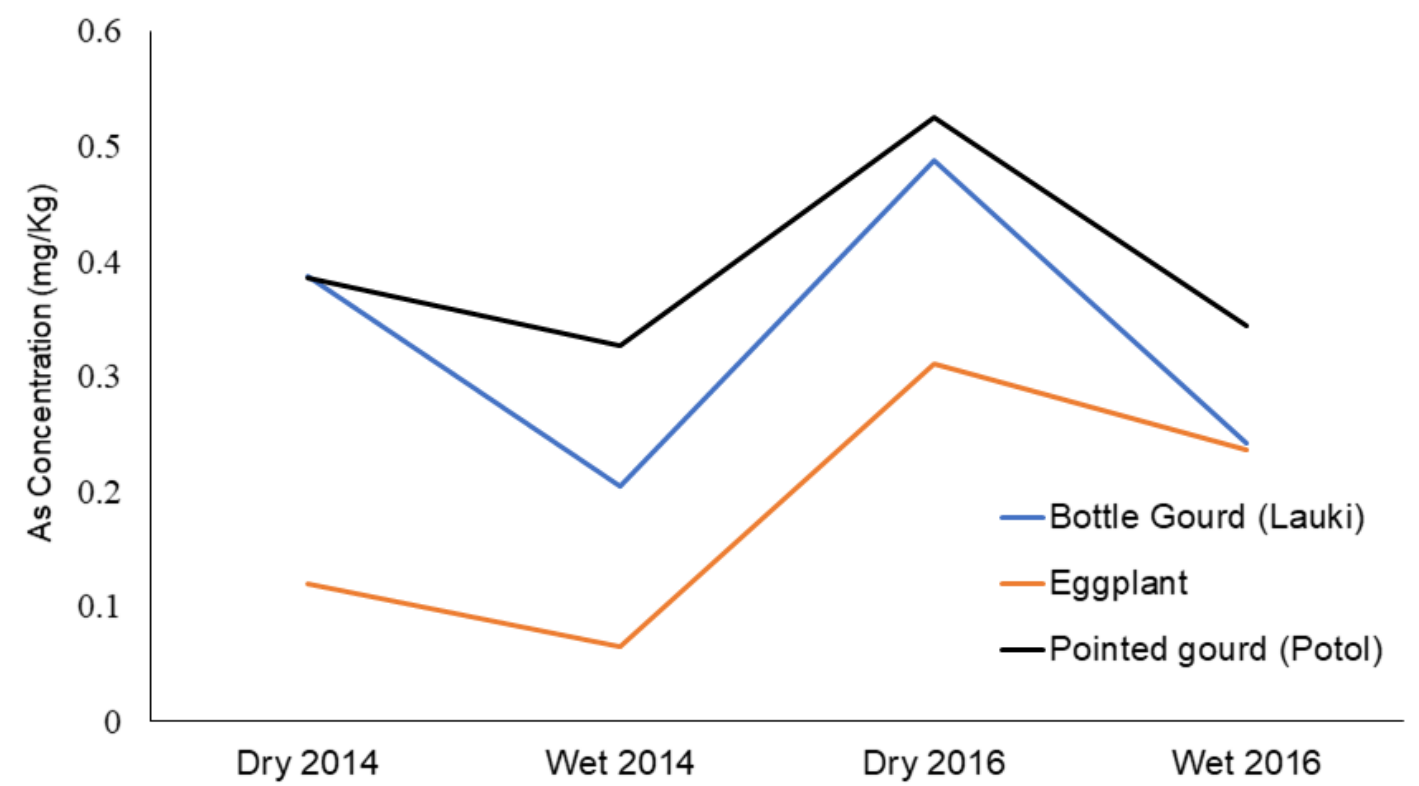

217 Fig. 5. The temporal changes in As concentration of pointed gourd, bottle gourd and eggplant

218 from the study site during boro and aman 2014 and 2016.

220 We also evaluated the As level in bovine milk and animal fodder (Shorghum bicolor) consumed by cattle. The milk samples were taken directly from lactating cows from stalls close to the paddy fields. Arsenic concentration in the milk samples in 12 sites across different time periods is indicated in Table 2. The average As concentration in milk samples varied from 0.06 to $0.24 \mu \mathrm{g} / \mathrm{L}$; the highest As concentration in milk sample was observed during boro 2016. The fodder concentration also varied leading to differential intake of As during different time periods.

Table 2. The average As concentration in milk and fodder collected from 12 sites, during different sampling periods.

\begin{tabular}{|c|c|c|}
\hline Sampling period & As in milk $(\mu \mathrm{g} / \mathrm{l})$ & As in fodder $(\mathrm{mg} / \mathrm{kg})$ \\
\hline Boro 2014 & $0.14(\mathrm{n}=12)$ & $3.32(\mathrm{n}=12)$ \\
\hline Aman 2014 & $0.06(\mathrm{n}=12)$ & $2.06(\mathrm{n}=12)$ \\
\hline Boro 2016 & $0.24(\mathrm{n}=33)$ & $2.63(\mathrm{n}=12)$ \\
\hline Aman 2016 & $0.13(\mathrm{n}=31)$ & $2.63(\mathrm{n}=12)$ \\
\hline
\end{tabular}


Detection and monitoring the As fluxes in groundwater and food crops is important to assess the potential health impacts on humans and other life-forms. Spatial and temporal variations in groundwater As concentration occurs mainly due to changing rainfall patterns, runoff and infiltration rates resulting in fluctuations in groundwater levels causing As mobilization and redistribution in the aquifer (Bhattacharya et al. 2007; Nath et al. 2008; Ghosh et al. 2015; 2017; Mukherjee 2018). These studies reported specific trends in the temporal variability of As in groundwater from different regions (Duan et al. 2015 and references therein). In the present study, As levels in groundwater were consistently low during aman caused by the recharge from monsoon precipitation (Fig.2). Irrigation during the water-deficient periods and evaporation can result in differences in shallow aquifers resulting in higher As variability. Reductive dissolution and desorption of As caused by increased water level can counter the dilution effect caused by precipitation-derived recharge but this was not relevant in the present study (Duan et al. 2015; Williams and Oostrom 2000). The results of our study are concordant with the study conducted by (Brikowski et al. 2014) in the Ganges flood plains of Nepal. Groundwater As concentration showed an increasing trend during the monitoring period and the reason(s) remain unclear but possibly this could be due to the temporal mobilization favoured by geogenic conditions and anthropogenic processes (Ghosh et al., 2014, 2018). Except for the rainy season, the agricultural fields were routinely irrigated by groundwater from shallow tube wells. Arsenic has a high affinity for metal-oxides and hydroxides present in soils, and it accumulates in agricultural fields causing As concentrations to increase in soils (Ahsan and del Valls 2011). This inference is supported by a significant positive correlation between As concentration in irrigation waters and soils from agricultural fields in the study region (Fig.3b).

Arsenic levels in topsoil are expected to increase in the near future unless continuous irrigation of contaminated groundwater is significantly reduced over the years. The monsoon flooding of paddy fields can often lead to vertical mixing of As from topsoil followed by lateral transport to nearby water bodies when the flooding has receded (Roberts et al. 2010). Thus, annual flooding during monsoon removes As accumulated in soil, and thereby, phytotoxicity risks. However, the present study clearly indicated that seasonal variability in the region did not reduce the overall potential for As accumulation in soils. This resulted in an enhanced risk of As accumulation in food crops that will continue. The results support our hypothesis that withdrawal of As contaminated groundwater for irrigation in the last couple of decades has led to elevated As levels in the soil. These concentrations are expected to 
increase with time in the Bengal basin due to current land-use practice s (Rahman, Hasegawa, and Rahman 2007). Further validation of this conjecture requires long term monitoring and extensive sampling from the region.

\subsection{Arsenic in rice}

Rice is the staple food and a major source of carbohydrates in most Asian diets. Chronic exposure to As, through rice, is a major health concern, and As concentration in rice varies depending on the uptake rates, environmental conditions, agricultural practices, and the rice processing methodology (Meharg et al. 2008; FAO 2011). Higher levels of As in rice grain results mainly due to irrigation from contaminated groundwater, mining, industrial activity and also from the use of As-based pesticides (Meharg et al. 2008). A study from the Bengal basin reported that an adult incorporates ca. $2.32 \mu \mathrm{g} / \mathrm{kg}$ of As in terms of the bodyweight (wt) per day which exceeds the WHO potential daily intake of $2.1 \mu \mathrm{g}$ As $\mathrm{kg}-1$ body wt/day (Roychowdhury 2008).

The practice of submerged rice cultivation commonly followed in India, creates anaerobic condition, whereby arsenate $[\mathrm{As}(\mathrm{V})]$ in soil is converted to the more toxic arsenite $[\mathrm{As}(\mathrm{III})]$ species which is then desorbed from pedogenic minerals. Following desorption, they are taken up by NIPs and translocated through xylem (Ma et al. 2008; Yamaguchi et al. 2014). Intense irrigation during the boro season gradually increases As fluxes in the top-soil that can affect rice cultivation paddy cultivation (van Geen et al. 2006).

The results in this study indicate that As levels in boro rice is 3 times higher than the aman harvest season rice (Fig. 4a). During boro, excessive irrigation using groundwater (i.e. $\sim 1000$ $\mathrm{mm}$ per season can lead to As accumulation of up to $1 \mu \mathrm{g} / \mathrm{g}$ soil per year (Meharg and Rahman 2003). Temporal increase of As concentration in groundwater during the boro season along with intense irrigation facilitates accumulation of As in food crops (Fig. 4a). Irrigation with As contaminated ground water leads to the accumulation of As in soil, which eventually causes toxicity in the food crops. Polishing is the major step during rice processing and this procedure can greatly reduce the As concentration in rice kernels (Meharg et al. 2008; Naito et al. 2015). Since As is mainly localized in upper coat or epidermis of the grain (i.e. pericarp and the aleurone layer), it is largely removed during polishing thereby reducing the total As content in grain (Meharg et al. 2008). The raw rice kernels are polished during which the outer layers are removed from the grain before it is sold in the market. Our study indicates 
that polishing reduced the As content in rice up to $82 \%$ during dry season and $79 \%$ during the wet season. Consumption of unpolished rice such as brown rice in which the outer layer tends to accumulate higher As and pose a significant health risk to humans (Chikkanna et al., 2019). Hence, As levels in rice kernels need to be evaluated closely due to its high spatial variability in soil leading to differential accumulation of As in rice grains produced indifferent regions. It is also important to point out that the average contribution of rice to total As intake is ca. $56 \%$ which is quite high when compared to drinking water which only contributes upto13\% (Ohno et al. 2007). Thus, the consumption of rice sold in market of unknown provenance or generic labelling (and not specifying the type area) poses a dilemma.

\subsection{Arsenic in vegetables}

Many regions in BDP use As contaminated groundwater from shallow tube wells for irrigation purposes leading to As accumulation and phytotoxicity in crops (Bhattacharya, Samal, and Majumdar 2010; Das et al. 2004; Roychowdhury et al. 2002). Arsenic concentration in vegetables from the current study ranges from 0.001 to $1.03 \mathrm{mg} / \mathrm{kg}$ which falls within the global range of $<0.01$ to about $5 \mathrm{mg} / \mathrm{kg}$ (Mandal and Suzuki 2002). Except the pointed gourd sample (with $1.03 \mathrm{mg} / \mathrm{kg} \mathrm{As}$ ), all other vegetables fall under the safe food hygiene limit which is consistent with the previous study in Nadia district (Bhattacharya et al. 2010). Our study indicates that accumulation of As is high during both the boro harvest in rice grain compared to vegetables. The rural local population largely depends on both rice and vegetables for meals thrice a day. A similar trend in temporal changes of As content between groundwater from wells and vegetables indicates that As levels in food crops being influenced by the fluctuating As level in irrigation water. Our results support the study by Dahal et al. 2008 that the As content in food crops is correlated with the level of As in irrigation water. The highest concentration of As occurs in bottle and pointed gourd which also have the highest moisture content (Kumar and Singh 2012). But tomato with nearly 92\% moisture content had low As concentration indicating that uptake and accumulation of As in food crops depends mainly on the bioavailability and physiological properties of the plant (Bhattacharya et al. 2010; Correia et al. 2015).

\subsection{Arsenic in milk}

Consumption of As contaminated groundwater by animals can cause serious health impacts and also affect the quality of animal products (Panaullah et al. 2009). Livestock such as cow and buffalo are routinely fed contaminated groundwater and rice straw which are reported to 
have the highest level of As (Biswas, Biswas, and Santra 2014). The consequences of As contamination in livestock particularly the pathway to human exposure is the least studied aspect in As toxicity. The contaminant reaching the ruminant is diluted to a tolerable limit,

344 but chronic exposure can lead to As poisoning in the animals (Rana et al. 2014). In our study area, the cattle were fed mainly the forage crop Sorghum bicolor, which is also a Poaceae like paddy. The average concentration of As in milk in the current study was lower than the reported values of $21 \mu \mathrm{g} / \mathrm{L}$ and $72 \mu \mathrm{g} / \mathrm{L}$ reported by previous study from Nadia district (Datta et al. 2012; Datta et al. 2010).

Arsenic enters in the cattle mainly through the ingestion of fodder and drinking contaminated water. Concentration of As in turf water during aman 2016 was $119 \mu \mathrm{g} / \mathrm{L}$ which is lower than the groundwater As level but still high. Following the assumption that the average consumption of water and fodder is $55 \mathrm{~L}$ and $13.5 \mathrm{~kg}$, respectively, then almost $43 \mathrm{mg}$ of As per day is consumed by a lactating cow on-site during the aman season (Datta et al. 2012 and references within). The As excreted out through urine and faeces, which can further contaminate soil from the agricultural use of cow dung for fertilization (Rana et al. 2014). The As concentration in faeces is usually two times higher than urine, blood, and milk (Rana et al. 2014). In India, cow dung is commonly used as a fertilizer which provides another means of As transport from groundwater to the soil. Furthermore, Datta et al (2012) reported that the cattle milk consists entirely of inorganic As and toxic trivalent [As(III)] form dominates over the As(V), which makes milk a potent source of contamination in the food chain. Thus, in addition to water and consumption of common crops, milk or milk products increases the vulnerability for potential health risks and further contribute to the multiple reports on As-related health problems in the region. Increasing population in India and rising demand for higher production of food crops worsens the problem furthermore.

\section{Conclusions}

368 Overall, this work demonstrates the cultivation practices, food habits, and pathways of As intoxication in a rural population in Nadia district, West Bengal. More than $15 \%$ of the human population in the district are reported to be affected by drinking As contaminated water (Mazumder et al. 2010). Even though a few measures have been taken to supply clean water, the current study shows that there are other possible routes of contamination and transfer of the metalloid into the food chain. Seasonal variability was observed in As contamination levels in paddy and vegetable samples collected during the boro and aman 
harvest seasons in 2014 and 2016. Polishing of rice grains can be an efficient way to reduce $(80 \%)$ the contaminant load but this reduces its nutritional value too. Overall, the plant families which require more water to grow (e.g. Poaceae) or the veggies with higher water content (e.g., Solanaceae) can be a major source of As compared to other crops. The other detected route of As uptake is via milk. The contaminated animal fodder and water can lead to high levels of As in dairy products, fed mostly to children that can lead to long term exposure and increased risks. The possible non-conventional routes of As transport and accumulation discussed herein are essential to devise strategies and practices to minimize As exposure.

\section{Acknowledgements}

The authors would like to acknowledge the Linköping University for providing instrumentation facility and the Swedish Research Link-Asia Program (Grant No. 348-20096470) awarded to JR to support the research. DG thanks the Department of Science and Technology, Government of India (Grant No. DST/INSPIRE/04/2015/002362), for partial support. SPK thanks the Indian Institute of Science and Inspire DST, Bangalore for the MS fellowship. The authors thank Prof. Abhijit Mukherjee, his group and Molly Aylesbury for assisting in sample collection and Dr. Mårten Dario and Lena Lundman who helped in the analysis.

\section{Declaration of interest statement}

All authors declare that there is no conflict of interest.

\section{References}

Ahsan, D. A., and T. A. del Valls. 2011. "Impact of Arsenic Contaminated Irrigation Water in Food Chain: An Overview from Bangladesh.” International Journal of Environmental Research, 5:627-638. doi:10.22059/ijer.2011.370.

Banerjee, Mayukh, Nilanjana Banerjee, Pritha Bhattacharjee, Debapriya Mondal, Paul R. Lythgoe, Mario Martínez, Jianxin Pan, David A. Polya, and Ashok K. Giri. 2013. "High Arsenic in Rice Is Associated with Elevated Genotoxic Effects in Humans." Scientific Reports 3: 2195. doi:10.1038/srep02195. 
408

409

410

411

412

413

414

415

416

417

418

419

420

421

422

423

424

425

426

427

428

429

430

431

432

433

434

435

436

437

438

439

Bhattacharya, P, A C Samal, and J Majumdar. 2010. “Arsenic Contamination in Rice, Wheat , Pulses , and Vegetables : A Study in an Arsenic Affected Area of West Bengal, India," Water, Air, \& Soil Pollution, 3-13. doi:10.1007/s11270-010-0361-9.

Bhattacharya, Prosun, Alan H. Welch, Kenneth G. Stollenwerk, Mike J. McLaughlin, Jochen Bundschuh, and G. Panaullah. 2007. Arsenic in the Environment: Biology and Chemistry. Science of the Total Environment, 379:109-120. doi:10.1016/j.scitotenv.2007.02.037.

Biswas, Anirban, Saroni Biswas, and Subhas Chandra Santra. 2014. "Arsenic in Irrigated Water, Soil, and Rice: Perspective of the Cropping Seasons." Paddy and Water Environment, 12 (4): 407-12. doi:10.1007/s10333-013-0396-9.

Brikowski, T H, A Neku, S D Shrestha, and L S Smith. 2014. "Hydrologic Control of Temporal Variability in Groundwater Arsenic on the Ganges Floodplain of Nepal.” Journal of Hydrology, 518:342-53. doi:10.1016/j.jhydrol.2013.09.021.

Chikkanna, A., L. Mehan, P.K. Sarath, D. Ghosh. 2019. Arsenic Exposures, Poisoning, and Threat to Human Health: Arsenic Affecting Human Health. In P. Papadopoulou, C. Marouli, \& A. Misseyanni (Eds.), Environmental Exposures and Human Health Challenges pp. 86105. Hershey, PA: IGI Global. doi:10.4018/978-1-5225-7635-8.ch004

Correia, A. F.K., A. C. Loro, S. Zanatta, M. H.F. Spoto, and T. M.F.S. Vieira. 2015. "Effect of Temperature, Time, and Material Thickness on the Dehydration Process of Tomato." International Journal of Food Science Hindawi Publishing Corporation. doi:10.1155/2015/970724.

Dahal, B. M., M. Fuerhacker, A. Mentler, K. B. Karki, R. R. Shrestha, and W. E.H. Blum. 2008. "Arsenic Contamination of Soils and Agricultural Plants through Irrigation Water in Nepal.” Environmental Pollution 155:157-63. doi:10.1016/j.envpol.2007.10.024.

Das, H K, A K Mitra, P K Sengupta, A Hossain, F Islam, and G H Rabbani. 2004. “Arsenic Concentrations in Rice, Vegetables, and Fish in Bangladesh : A Preliminary Study" 30: 383-87. doi:10.1016/j.envint.2003.09.005. 
441 Bhatacharya, Animesh K. Chakraborty, and Tapan K. Mandal. 2010. "Chronic Arsenicosis in

442 Cattle with Special Reference to Its Metabolism in Arsenic Endemic Village of Nadia District 443 West Bengal India.” Science of the Total Environment, 409:284-88.

444 doi:10.1016/j.scitotenv.2010.10.003.

446 Datta, Bakul Kumar, Moloy Kumar Bhar, Pabitra Hriday Patra, Debasish Majumdar, Radha

447 Raman Dey, Samar Sarkar, Tapan Kumar Mandal, and Animesh Kumar Chakraborty. 2012.

448 "Effect of Environmental Exposure of Arsenic on Cattle and Poultry in Nadia District, West

449 Bengal, India.” Toxicology International, 19:59-62. doi:10.4103/0971-6580.94511.

450

451 Dennis, Sherri, Suzanne Fitzpatrick, Katie Egan, Brenna Flannery, Richard Kanwal, Deborah 452 Smegal, Judi Spungen, and Shirley Tao. 2016. “Arsenic in Rice and Rice Products Risk 453 Assessment Report Center for Food Safety and Applied Nutrition Food and Drug

454 Administration Arsenic in Rice and Rice Products Risk Assessment Report Progress: Risk Management Team Review: Draft Risk Assessment Report.”

http://www.fda.gov/Food/FoodScienceResearch/RiskSafetyAssessment/default.htm.

Duan, Yanhua, Yiqun Gan, Yanxin Wang, Yamin Deng, Xinxin Guo, and Chuangju Dong.

460 2015. "Temporal Variation of Groundwater Level and Arsenic Concentration at Jianghan

461 Plain, Central China.” Journal of Geochemical Exploration, 149:106-19.

462 doi:10.1016/j.gexplo.2014.12.001.

463

464 Geen, A. van, Y. Zheng, Z. Cheng, Y. He, R.K. Dhar, J.M. Garnier, J. Rose, A. Seddique, 465 M.A. Hoque, and K.M. Ahmed. 2006. "Impact of Irrigating Rice Paddies with Groundwater 466 Containing Arsenic in Bangladesh.” Science of The Total Environment, 367:769-77.

467 doi:10.1016/J.SCITOTENV.2006.01.030.

468

469 Ghosh, D., Bhadury, P., and Routh, J. 2014. "Diversity of Arsenite Oxidizing Bacterial

470 Communities in Arsenic-Rich Deltaic Aquifers in West Bengal, India." Frontiers in

471 Microbiology, 5:602. doi:10.3389/fmicb.2014.00602.

472 
473 Ghosh, D., Routh, J., and Bhadury, P. 2017. "Sub-Surface Biogeochemical Characteristics and Its Effect on Arsenic Cycling in the Holocene Gray Sand Aquifers of the Lower Bengal Basin.” Frontiers in Environmental Science, 5:82. doi:10.3389/fenvs.2017.00082.

Ghosh, D., Routh., Dario, M., and Bhadury, P. 2015. "Elemental and Biomarker

Characteristics in a Pleistocene Aquifer Vulnerable to Arsenic Contamination in the Bengal

Delta Plain, India.” Applied Geochemistry, 61: 87-98. doi:10.1016/j.apgeochem.2015.05.007.

Joint FAO/WHO Expert Committee on Food Additives. Meeting (72nd : 2010 : Rome, Italy),

World Health Organization \& Food and Agriculture Organization of the United Nations. (2011). Safety evaluation of certain contaminants in food: prepared by the Seventy-second meeting of the Joint FAO/WHO Expert Committee on Food Additives (JECFA). World Health Organization.

486

Kabata-Pendias, Alina. 2001. Chapter 10, Elements of Group V, Arsenic. Trace Elements in Soils and Plants, Third Edition. Vol. 3rd. doi:10.1201/b10158-25.

Kumar, S., and B. D. Singh. 2012. "Pointed Gourd: Botany and Horticulture.” In

Horticultural Reviews, 203-38. Hoboken, NJ, USA: John Wiley \& Sons, Inc. doi:10.1002/9781118100592.ch5.

Ma, J.F., N. Yamaji, N. Mitani, Xiao-Yan Xu, Yu-Hong Su, Steve P McGrath, and Fang-Jie Zhao. 2008. "Transporters of Arsenite in Rice and Their Role in Arsenic Accumulation in Rice Grain." Proceedings of the National Academy of Sciences of the United States of America 105: 9931-35. doi:10.1073/pnas.0802361105.

Mandal, B.K., and Suzuki, K.T. 2002. "Arsenic Round the World: A Review.” Talanta. Elsevier. doi:10.1016/S0039-9140(02)00268-0.

Mazumder, D.N., Ghosh, A., Majumdar, K., Ghosh, N., Saha, C., and Mazumder, R.N. 2010. "Arsenic Contamination of Ground Water and Its Health Impact on Population of District of doi:10.4103/0970-0218.66897. 
Meharg, A. A., Lombi, E., Williams, P.N., Scheckel, K.G., Feldmann, J., Raab, A., Zhu, Y., and Islam, R. 2008. "Speciation and Localization of Arsenic in White and Brown Rice Grains.” Environmental Science \& Technology 42:1051-57. doi:10.1021/es702212p.

Meharg, A. A., and Rahman, M. 2003. "Arsenic Contamination of Bangladesh Paddy Field

Soils: Implications for Rice Contribution to Arsenic Consumption." Environmental Science \& Technology 37:229-34. doi:10.1021/es0259842.

514

Mukherjee, A. 2018. Groundwater of South Asia. Edited by Abhijit Mukherjee. 1st ed.

Naito, S., Matsumoto, E., Shindoh, K., and Nishimura. T. 2015. "Effects of Polishing, Cooking, and Storing on Total Arsenic and Arsenic Species Concentrations in Rice Cultivated in Japan." Food Chemistry, 168: 294-301.

doi:10.1016/J.FOODCHEM.2014.07.060.

Nath, B., Z. Berner, S. Basu Mallik, D. Chatterjee, L. Charlet, and D. Stueben. 2005.

"Characterization of Aquifers Conducting Groundwaters with Low and High Arsenic

Concentrations: A Comparative Case Study from West Bengal, India.” Mineralogical Magazine 69: 841-54. doi:10.1180/0026461056950292.

Nath, B., Sahu, S.J., Jana, J., Mukherjee-Goswami, A., Roy, S., Sarkar, M.J., and Chatterjee, D. 2008. "Hydrochemistry of Arsenic-Enriched Aquifer from Rural West Bengal, India: A Study of the Arsenic Exposure and Mitigation Option." Water, Air, and Soil Pollution 190: 95-113. doi:10.1007/s11270-007-9583-x.

Nickson, R., J. McArthur, W. Burgess, K. Matin Ahmed, P. Ravenscroft, and M. Rahman. 1998. “Arsenic Poisoning of Bangladesh Groundwater.” Nature 395: 338 doi:10.1038/26387.

Norra, S., Z.A. Berner, P. Agarwala, F. Wagner, D. Chandrasekharam, and D. Stüben. 2005. doi:10.1016/j.apgeochem.2005.04.019. 
541 Ohno, K., T. Yanase, Y. Matsuo, T. Kimura, Md. H. Rahman, Y. Magara, and Y. Matsui.

542 2007. "Arsenic Intake via Water and Food by a Population Living in an Arsenic-Affected

543 Area of Bangladesh." Science of the Total Environment, 38:68-76.

544 doi:10.1016/j.scitotenv.2007.03.019.

545

546 Panaullah, G. M., Alam, T., Hossain, M.B., Loeppert, R.H., Lauren, J. G., Craig A. Meisner, 547 Z.U. Ahmed, and J.M. Duxbury. 2009. "Arsenic Toxicity to Rice (Oryza sativa L.) in 548 Bangladesh.” Plant and Soil, 317:31-39. doi:10.1007/s11104-008-9786-y.

Rahman, M.A., H. Hasegawa, and M.M. Rahman. 2007. “Accumulation of Arsenic in Tissues of Rice Plant (Oryza Sativa L .) and Its Distribution in Fractions of Rice Grain" Chemosphere, 69: 942-48. doi:10.1016/j.chemosphere.2007.05.044.

Rana, T., Bera, A.K., Das, S., Bhattacharya, D., Pan, D., Das, S.K. 2014. “Subclinical Arsenicosis in Cattle in Arsenic Endemic Area of West Bengal, India." Toxicology and Industrial Health 30:328-35. doi:10.1177/0748233712456061.

Roberts, L. C., S.J. Hug, J. Dittmar, A. Voegelin, R. Kretzschmar, B. Wehrli, O.A. Cirpka, G.C. Saha, M.A. Ali, and A.B.M. Badruzzaman. 2010. "Arsenic Release from Paddy Soils during Monsoon Flooding." Nature Geoscience 3: 53-59. doi:10.1038/ngeo723.

Roychowdhury, T., T. Uchino, H. Tokunaga, and M. Ando. 2002. "Survey of Arsenic in Food Composites from an Arsenic-Affected Area of West Bengal, India" Food and Chemical Toxicology, 40: 1611-21.

Upadhyay, M. K., A. Majumdar, A. Barla, S. Bose, and S. Srivastava. 2019. “An Assessment of Arsenic Hazard in Groundwater-Soil-Rice System in Two Villages of Nadia District, West Bengal, India.” Environmental Geochemistry and Health, 41: 2381-95. doi:10.1007/s10653-019-00289-4.

Williams, M.D., and M. Oostrom. 2000. "Oxygenation of Anoxic Water in a Fluctuating 230:70-85. doi:10.1016/S0022-1694(00)00172-4. 
575 Yafa, C., J.G., Farmer, M.C. Graham, J.R. Bacon, C. Barbante, W.R.L. Cairns, R. Bindler, I. 576 Renberg, A. Cheburkin, H. Emons, M.J. Handley, S.A. Norton, M. Krachler, W. Shotyk, 577 X.D. Li, A. Martinez-Cortizas, I.D. Pulford, V. MacIver, J. Schweyer, E. Steinnes, T.E.

578 Sjobakk, D. Weiss, A. Dolgopolova, M. Kylander. 2004. “'Development of an ombrotrophic 579 peat bog (low ash) reference material for the determination of elemental concentrations."

580 Journal of Environmental Monitoring 6:493-501. https://doi.org/10.1039/b315647h

581

582 Yamaguchi, N., T. Ohkura, Y. Takahashi, Y. Maejima, and T. Arao. 2014. "Arsenic

583 Distribution and Speciation near Rice Roots Influenced by Iron Plaques and Redox

584 Conditions of the Soil Matrix.” Environmental Science \& Technology, 48:1549-56.

585 doi:10.1021/es402739a.

586

587 https://en.climate-data.org/asia/india/west-bengal/krishnanagar-24509/ 